\title{
Diverse rates of gene flow and long-distance migration in two moose Alces alces subpopulations in Europe
}

\author{
Magdalena Niedziałkowska $^{1}$ - Bogumila Jędrzejewska ${ }^{1}$ - Jan Danyłow ${ }^{2}$. \\ Krzysztof Niedzialkowski ${ }^{1}$
}

Received: 29 January 2016 / Accepted: 7 April 2016/Published online: 18 April 2016

(C) The Author(s) 2016. This article is published with open access at Springerlink.com

\begin{abstract}
We assessed migration rates and gene flow amongst 16 local demes and six larger groups of moose identified by a previous microsatellite study across the entire European range of the species. The most important barrier to gene flow, the Baltic Sea along with the mountainous region in northern Fennoscandia, separates two genetically distinct moose subpopulations - the Scandinavian and the continental subpopulations - that originate from different glacial refugia. Our results showed that moose effectively migrated over long distances, but statistically significant gene flow was shorter in the Scandinavian (300-400 km) compared to the continental subpopulation (400-500 km). The admixture rates in local demes were markedly lower in the Scandinavian, than in the continental part of the moose range. Weaker gene flow amongst local demes in Scandinavia resulted from the major barrier of the Scandinavian Mountains. In the generally panmixed continental subpopulation of moose, two demes-one in NE Poland and another in the Kirov Oblast, Russia showed slightly hampered gene exchange with neighbouring demes, whereas one deme, in Arkhangelsk region, NE part of European Russia, appeared to have very high gene flow into other demes. Different evolutionary and demographic histories, population densities and land topography (large rivers) could
\end{abstract}

Communicated by: Cino Pertoldi

Electronic supplementary material The online version of this article (doi:10.1007/s13364-016-0274-0) contains supplementary material, which is available to authorized users.

Magdalena Niedziałkowska

mniedz@ibs.bialowieza.pl

1 Mammal Research Institute Polish Academy of Sciences, 17-230 Białowieża, Poland

2 Kampinos National Park, ul. Tetmajera 38, 05-080 Izabelin, Poland have contributed to the low level barriers to gene flow in the continental subpopulation of moose.

Keywords Microsatellite DNA · Assignment test . First-generation migrants $\cdot$ Migration barriers $\cdot$ The Scandinavian subpopulation $\cdot$ The continental subpopulation

\section{Introduction}

Spatial movements and gene flow are some of the most important processes which shape the genetic structure of mammal populations. Large herbivores are an interesting group of mammals in this respect as they include both sedentary and migratory species (Harris et al. 2009). Some species, such as moose Alces alces, also show high intraspecific variation in dispersal and migratory behaviour. Movement patterns of moose can vary between years and seasons and with the environmental conditions in the areas which they occupy (Singh et al. 2012). It has been observed that some moose are able to migrate up to $800 \mathrm{~km}$ in Eurasia (Rozhkov et al. 2009) and even over $1500 \mathrm{~km}$ in North America (Hoffman et al. 2006). However, seasonal migrations are shorter: between 100 and $300 \mathrm{~km}$ in Russia (Filonov 1983), up to about $100 \mathrm{~km}$ in Scandinavia (Singh et al. 2012) and between 65 and $179 \mathrm{~km}$ in North America (Filonov 1983 and references therein).

Singh et al. (2012) classified the movement behaviour of moose into different categories: migration, dispersal, nomadism and residence. Migration was defined as a seasonal movement with a return to the place of departure. Analysis of moose populations in Sweden showed a clear latitudinal pattern to their migratory behaviour (Singh et al. 2012). The share of seasonal migrants in a population declined from $95 \%$ in northern $\left(66^{\circ} \mathrm{N}\right)$ to $39 \%$ in southern Sweden $\left(56^{\circ} \mathrm{N}\right)$, and their mean migration distance 
declined from 103 to $5 \mathrm{~km}$, respectively. An exception was the population at $67^{\circ} \mathrm{N}$, in the mountains, which undertook short (mean $30 \mathrm{~km}$ ) altitudinal migrations. Data from SE Poland (Polesie region $51.45^{\circ} \mathrm{N}$ ) conforms to this latitudinal gradient: two-thirds of individuals showed short distance (mean $7 \mathrm{~km}$ ) seasonal migrations (M. Ratkiewicz, R. Kowalczyk and co-workers, unpublished data).

Global analysis performed by Harris et al. (2009) revealed that many populations of different species of ungulates have stopped migrating seasonally in recent times due to changes in the environment, climate changes and over-exploitation. Some populations of moose were also reported to have changed their behaviour in historical times. For example, in the eighteenth century, moose from the Białowieża Primeval Forest in eastern Poland migrated seasonally to the Polesye marshes (currently in Belarus) (Brincken 1826), but in present times, the local population has become sedentary and lives in the forest over the whole year (Jędrzejewska and Jędrzejewski 1998). Such great spatial and temporal variation in the movement behaviour of European moose has obviously had consequences for gene exchange between different population units.

A population genetic study (based on mtDNA and microsatellites) of European moose showed a strong division between Scandinavian and continental subpopulations. The Scandinavian cluster (a single mtDNA lineage) has the lowest genetic diversity according to analyses of both mitochondrial and microsatellite DNA (Niedziałkowska et al. 2014, 2016). The continental subpopulation consists of two mtDNA lineages and three microsatellite clusters with overlapping ranges. The European-scale genetic structuring of moose is mainly shaped by their evolutionary history, postglacial migration routes and the presence of large migration barriers such as the Baltic Sea (Niedziałkowska et al. 2014, 2016). However, the division of the continental subpopulation into microsatellite clusters probably reflects the more recent history of the species, during which humans have had a stronger impact (Niedziałkowska et al. 2016).

In this paper, we estimated the large-scale pattern of gene flow in European moose. Population genetics studies are especially useful for detecting long-distance gene flow and connectivity amongst populations, although they are not able to detect the movement of individuals at a local scale as e.g. telemetry studies do (Finnegan et al. 2012). On the other hand, molecular analyses allow the assessment of the real gene flow between populations, which is difficult to estimate based on the number of observed dispersal cases from telemetry studies (Riley et al. 2006).

The aims of our paper were to assess the migration rate and gene flow amongst different local populations of moose in Europe, to estimate the spatial distance at which gene exchange is possible and to find the major migration barriers for the species across its European range. To the best of our knowledge, this study is one of the few to assess the pattern of gene flow of a species at a continental scale.

\section{Material and methods}

\section{Sampling, DNA extraction and genotyping}

Moose tissue samples were collected in 10 European countries: Poland, Norway, Sweden, Finland, Estonia, Latvia, Lithuania, Belarus, Russia and Ukraine. The study area covered almost the whole of the continuous European range of moose and included the 16 local populations (demes) and six genetically distinct groups of the species (Fig. 1) indicated by an earlier study (Niedziałkowska et al. 2016). In all countries except Poland, tissue samples were collected from legally hunted animals. In Poland, where moose are protected by law, samples were collected from animals found dead due to natural mortality factors or killed on the roads. We stored all samples at $-20{ }^{\circ} \mathrm{C}$ prior to DNA extraction. We extracted DNA from tissue samples (e.g. muscles, parts of the internal organs or skin) using commercial kits (DNeasy Blood and Tissue Kit; Qiagen) according to the manufacturer's instructions. Genotyping was performed using 694 moose tissue samples and 14 microsatellite loci according to the protocol described in detail by Niedziałkowska et al. (2016).

\section{Statistical analyses}

For the statistical analyses, we used the same set of moose microsatellite data which we used previously in Niedziałkowska et al. (2016). In this paper, we assessed gene flow at two spatial levels (Fig. 1): (1) amongst the 16 demes using an assignment test and (2) using a test to identify firstgeneration migrants (statistics chosen: Likelihood ratio $\mathrm{L}$ home/L max) amongst the six genetic groups of moose indicated by STRUCTURE 2.3.4 (Pritchard et al. 2000; Falush et al. 2003) and presented in Niedziałkowska et al. (2016). Both tests were implemented in GENECLASS 2 (Piry et al. 2004), and for both we used a Bayesian framework (Rannala and Mountain 1997) using the following parameter sets: 10000 MCMC iterations (10 000 simulated individuals) and a threshold $p$ value (type I error $\alpha$ ) of 0.01 . For the assignment test, we calculated probability (Monte Carlo resampling) using the method of Paetkau et al. (2004). As one of the indicators of gene flow between the 16 moose demes, we used a measure of misassignment probability: the assignment of moose to a deme different than the deme of sampling, as proposed by Castric and Bernatchez (2004). For firstgeneration migrants, the method of Cornuet et al. (1999) was applied. The test for first-generation migrants is sensitive to highly variable sample sizes of compared populations. Our demes contained from 9 to 78 moose, and the largest demes 
Fig. 1 Map of the study area. Distribution of the 16 demes and six moose groups indicated by the analysis of microsatellite DNA (Niedziałkowska et al. 2016)

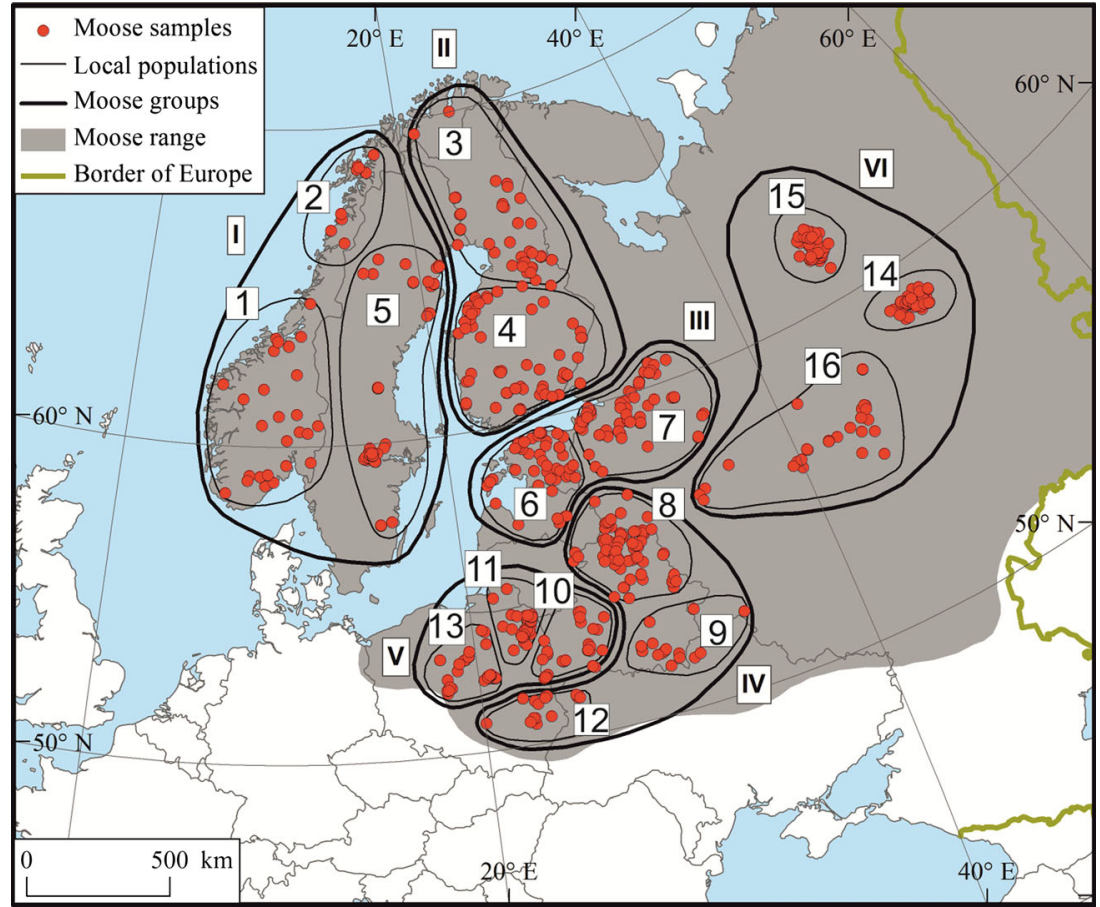

tended to show a 2-3-fold higher number of immigrants than the smallest deme $(r=0.40, N=16, p=0.12)$. Sample sizes of the six groups varied from 97 to 132 moose (Fig. 1); thus, the analysis did not violate the assumption of the test. The number of first generation immigrants was not correlated with the number of samples analysed in the groups $(r=-0.116, N=6$, $p=0.83)$. Several first-generation migrants recognised by GENECLASS 2 had a similar probability of assignment to different groups; as real migrants, we only accepted those that differed in probability between different moose populations by about $1 \log (\mathrm{L})$.

We performed spatial autocorrelation analysis using 17 distance classes, 9999 permutations and 10,000 bootstraps in GENALEX 6.5 (Peakall and Smouse 2012). In this analysis, we correlated the genetic distances with geographic distances for (1) all individuals, (2) individuals within Scandinavia (including samples from demes 1, 2,5) and (3) individuals within the continental part of the moose range (including samples from demes 3, 4, 6-16).

As the previous study (Niedziałkowska et al. 2016) showed that the Baltic Sea is a serious migration barrier for moose, for all spatial analyses, we used the shortest land distances between individuals. The shortest land distances around the Baltic Sea were calculated using network analyst and Euclidean distances in Spatial Analyst in ARCGIS 10.2 (Redlands, CA: ESRI; 2012).

We used the software BARRIER v 2.2 (Manni et al. 2004) to identify barriers to gene flow in the European moose population. The software implements the Monmonier's (1973) maximum difference algorithm to calculate genetic barriers amongst studied populations of individuals. The algorithm identifies the zones where differences between pairs of populations are largest. As an input file, we used the coordinates of the 16 demes (calculated as the mean of the coordinates of individuals belonging to each deme) and matrices of genetic differentiation amongst them. In the first approach, we used the linear $\mathrm{F}_{\text {st }}$ matrix calculated in the software ARLEQUIN 3.5 (Excoffier and Lischer 2010), and in the second approach we identified barriers using a linear genetic distance matrix calculated in the software GENALEX 6.5 (Peakall and Smouse 2006, 2012). We compared the results of both approaches and chose 4 out of 10 barriers recognised by the software. These four barriers were identified in both approaches.

\section{Results}

Spatial autocorrelation analysis showed the fine-scale genetic structure and dispersal distances of moose in Europe. Statistically significant autocorrelation was detected up to a land distance of $300-400 \mathrm{~km}$ in the Scandinavian moose subpopulation and up to $400-500 \mathrm{~km}$ in the continental subpopulation (Fig. 2). In the whole European moose population, genetic structure was detected up to a land distance of 500 $600 \mathrm{~km}$. The two subpopulations also differed in their values for autocorrelation coefficients; the values were about twice as high in the Scandinavian than in the continental subpopulation. Moreover, in the Scandinavian subpopulation, the values of these coefficients were rather stable from 0 to $300 \mathrm{~km}$, but 

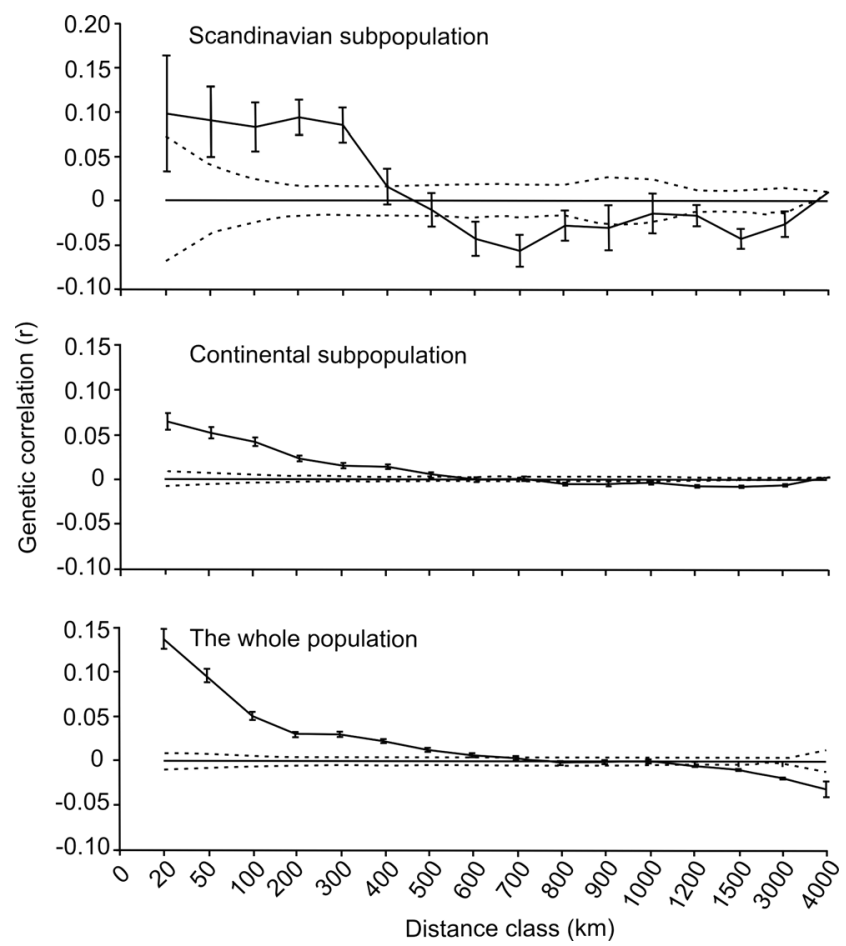

Fig. 2 Spatial autocorrelation in the Scandinavian moose subpopulation (upper panel), the continental subpopulation (middle) and amongst all individuals in the study area (lower panel). Error bars bound the $95 \%$ confidence interval for $r$ as determined by bootstrap resampling. Dotted line: confidence limits bound the $95 \%$ confidence limits for the null hypothesis of no spatial structure as determined by permutation. The distances were calculated as the shortest land distances around the Baltic Sea. Scandinavian subpopulation - group I, continental - groups II-VI (Fig. 1)

then quickly dropped down to 0 between 300 and $400 \mathrm{~km}$, whereas in the continental subpopulation $r$ values decreased slowly from 0 to $500 \mathrm{~km}$.

The assignment test showed that individuals generally had the highest mean probability of being prescribed to the deme where they had been found (Fig. 3, detailed data in Table R1 in Online Resource 1). In respect of gene exchange, it was also evident that demes belonging to the Scandinavian subpopulation (nos 1, 2 and 5) differed from all demes in the continental subpopulation. Not only was there very little gene flow between the two subpopulations, but amongst the three Scandinavian demes, the exchange of genes was also notably smaller than amongst the demes (nos 3, 4, 6-16) in the continental subpopulation (Fig. 3). In the latter case, four demes inhabiting Belarus and the Baltic States (nos 6-9) were characterised by very intense gene exchange, suggesting a panmixed population, and a high admixture from demes 15 and 16 in central and northern regions of European Russia (Fig. 3). Demes nos 10-13 (mainly Poland, western Belarus and western Ukraine) and deme 14 (the easternmost location in the area studied) were characterised by moderate indices of admixture (Fig. 3).
Misassignment, which is the assignment of moose to a deme different than the deme of sampling, is one of the indicators of gene flow. We expected that misassignment probability would decline with increasing geographic distance between source deme and deme of sampling (see Castric and Bernatchez 2004). Indeed, misassignment probabilities between each deme as a source population and all other demes, plotted against the pairwise geographic distance between them, showed that emigration rates from all source demes were significantly biassed towards proximate demes and declined with distance (Fig. R2 in Online Resource 2). Additionally, great inter-deme variation was observed; demes 1 and 2 (Southern and Northern Norway), isolated by the Scandinavian Mountains and the Baltic Sea, had the lowest rates of gene exchange with all other demes. In contrast, deme 15 (Arkhangelsk region, North of European Russia) showed very high genetic contribution to demes up to $2000 \mathrm{~km}$ away (Fig. R2 in Online Resource 2).

The most important barriers for gene flow in the European moose population, according to the results of analyses performed by the software BARRIER, are the Baltic Sea and the region in northern Scandinavia near the Norwegian, Swedish and Finish borders (Fig. 4). A secondary barrier for migration was detected in Scandinavia along the SwedishNorwegian border (Fig. 4). Two less significant barriers separate moose from deme 11 in north-eastern Poland and the Kaliningrad Oblast in Russia, which inhabit the western edge of the moose range in Europe, and individuals from deme 14 in the Kirov Oblast, Russia which inhabit the easternmost part of the study area (Fig. 4).

A total of 32 first-generation migrants $(4.6 \%$ of all analysed individuals) were recognised between the six studied groups based on GENECLASS results. The largest number of migrants (27) was detected within the continental part of the European moose range (Fig. 5). There was almost no exchange of migrants (except one case of a long-distance emigrant) between group I and groups III-VI. There were some emigrants from group II to other groups in continental Europe, but only one immigrant to this group from the southern groups. The mean land distance of migration amongst the six groups was $979 \mathrm{~km}$ (range: 136-2563 km, SE=95 km, the Baltic Sea was considered as a migration barrier), and the Euclidean distance was $873 \mathrm{~km}$ (range 124-1819 km, $\mathrm{SE}=76 \mathrm{~km})$.

\section{Discussion}

Our study is one of few which presents gene flow in a population of a terrestrial mammal at a spatial scale covering a large part of the continuous range of the species studied on one continent. All analyses showed a consistent pattern of moose migration in Europe. There is limited gene flow between the 
Fig. 3 Summary of the assignment test. Mean probability of assignment of moose from the 16 demes into each of the demes. In the first column - deme where individuals were found. Detailed data (means $\pm \mathrm{SE}$ in Online Resource 1)

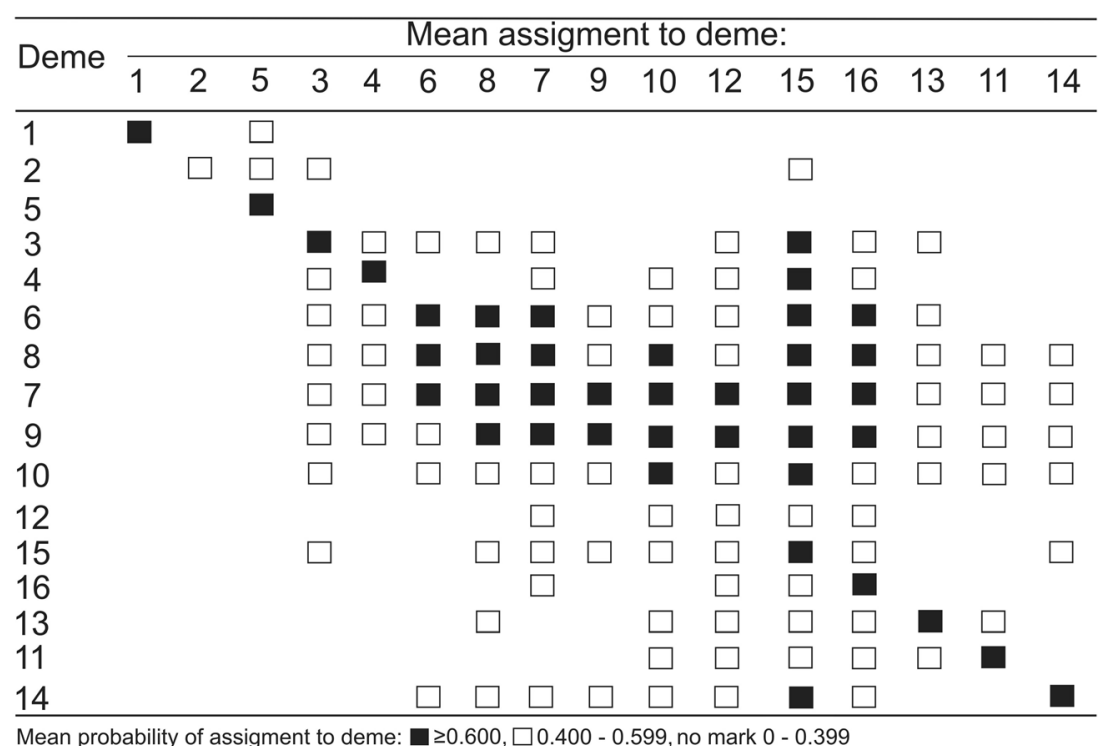

two genetically distinct European subpopulations of moose (Scandinavian and continental) recognised in previous studies (Niedziałkowska et al. 2014, 2016). Our analyses also showed limited gene flow within the Scandinavian subpopulation and very intensive gene flow amongst the continental demes. In Scandinavia, gene exchange occurred at shorter distances, and the genetic structure of the species was more visible compared to continental Europe. This pattern of gene flow corresponded well with the location of the main migration barriers detected in our study.

A similar pattern of intensive gene flow in mainland and low gene exchange between mainland and peninsular subpopulations were detected in a population of Alaskan caribou Rangifer tarandus granti (Mager et al. 2014). Also, high level of admixture and a lack of genetic structure were detected in the population of plains zebra (Equus quagga) inhabiting large areas of Africa (Lorenzen et al. 2008).

Intermediate gene flow was detected between the Finnish moose group (no. II) and other parts of the moose range. This was also visible in the genetic structure of moose in Finland (Niedziałkowska et al. 2016). According to the test of first generation migrants, more moose emigrated from group II to the southern part of the continent than vice-versa. This could be explained by harsher environmental conditions in Finland
Fig. 4 Major migration barriers to gene flow amongst the 16 demes in the European moose population, as indicated by the software BARRIER

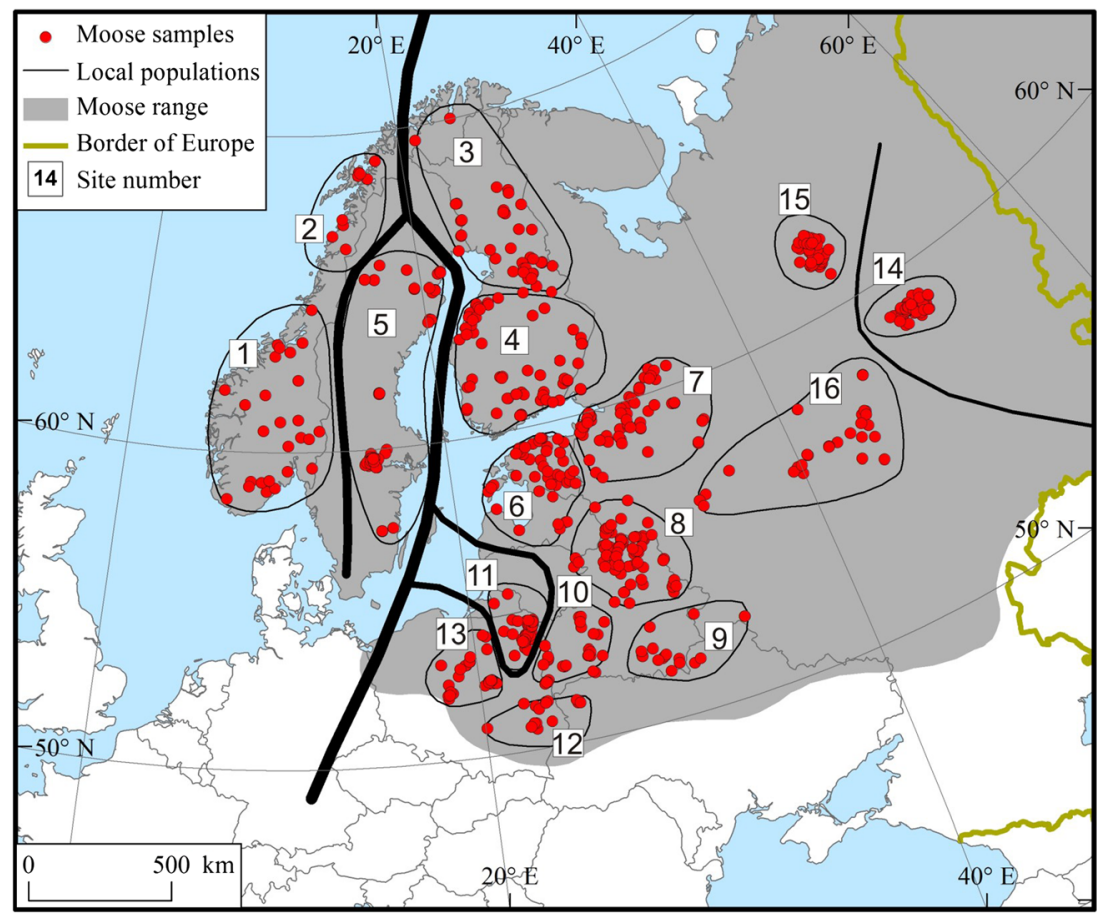


Fig. 5 First-generation migrants amongst six moose groups indicated by analyses of microsatellite DNA (see Niedziałkowska et al. 2016), as calculated in GENECLASS

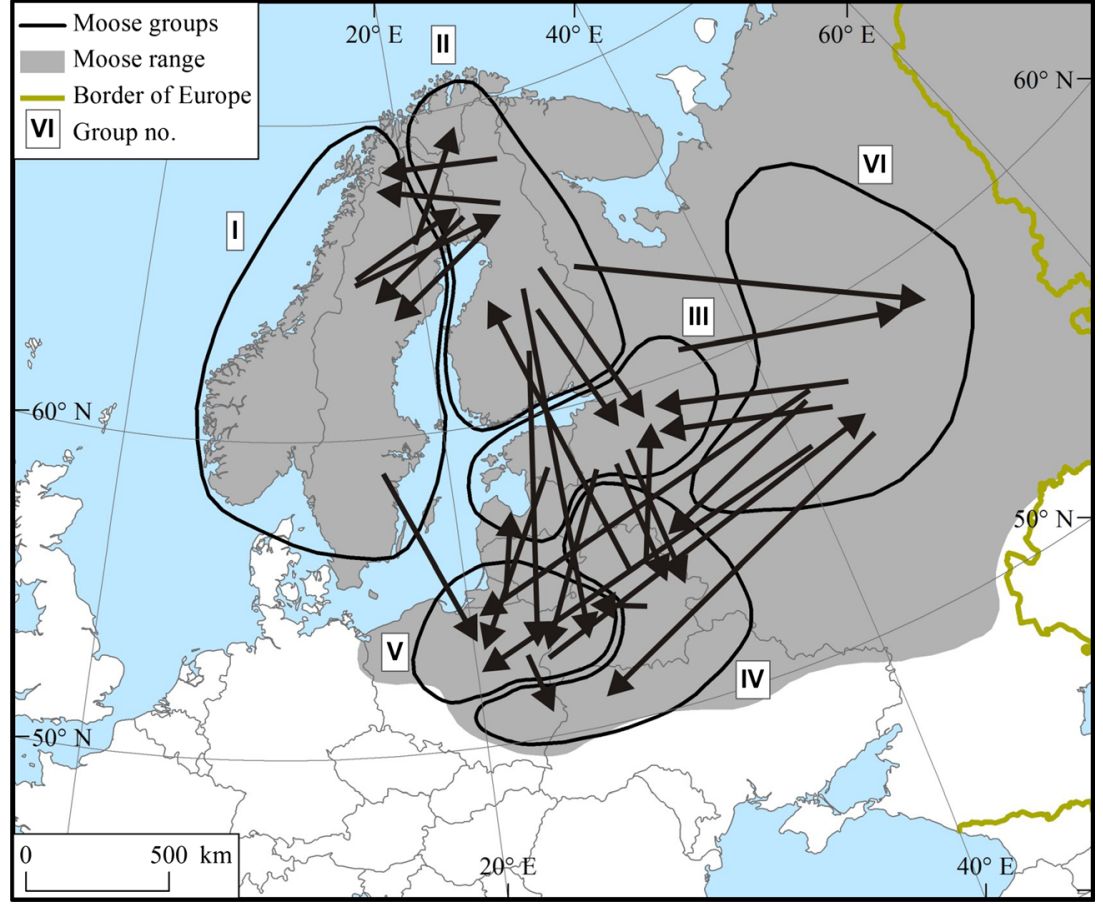

than in the more southern parts of continental Europe. Studies of movement behaviour of moose in Scandinavia showed that individuals from the northern part of the study area migrated seasonally much more often than moose inhabiting more southern regions; this was connected with the differences in snow depth (Singh et al. 2012).

The mean distance of migration of first-generation migrants was very large (close to $1000 \mathrm{~km}$ ). However, statistically significant gene flow was recorded at a shorter distance of 500-600 km. The fact that moose are able to migrate very large distances was already known from field observations (Dzięciołowski and Pielowski 1975; Hoffman et al. 2006; Rozhkov et al. 2009). In the continental subpopulation, the autocorrelation coefficient of genetic relatedness was significant at slightly larger distances than in the Scandinavian subpopulation, and its value slowly decreased with geographic distance. This indicates that the spatial genetic structure reflects the movement ability of moose rather than the presence of migration barriers. The opposite situation took place in the Scandinavian subpopulation. Larger values and a sharp decrease in the autocorrelation coefficient values at a distance of 300 $400 \mathrm{~km}$ probably indicates the presence of migration barriers which restrict the gene exchange within this subpopulation. However, other factors such as latitudinal variability of movement behaviour amongst moose populations in Scandinavia (Bunnefeld et al. 2011; Singh et al. 2012) could also have had an impact on the genetic structure of this subpopulation. A study performed on Alaskan caribou indicated that a sedentary herd differed genetically from a migratory herd even though both of them occurred in the same area (Mager et al. 2014).

The results of the analyses which estimated the gene flow between different moose demes and groups were in agreement with the analyses showing the distribution of the main migration barriers for moose in Europe. As shown by earlier studies on the genetic structure of European moose, the most important barriers, the Baltic Sea and the contact zone between these two subpopulations, which is located within the state borders of Sweden, Norway and Finland, separate the Scandinavian and continental subpopulations (Niedziałkowska et al. 2014, 2016). The very limited gene exchange which occurs within the area of this contact zone could be the result of topographical barriers such as mountains and broken coastline or the relatively recent contact of the subpopulations after postglacial migration from different Last Glacial Maximum refugia (Niedziałkowska et al. 2014, 2016). A significant migration barrier was also detected within the Scandinavian Peninsula, and this could be a consequence of the Scandinavian Mountain range (the Scandes), which has a maximum elevation of $2469 \mathrm{~m}$ a.s.l. Significant genetic substructuring of the Scandinavian moose subpopulation was also reported earlier by Haanes et al. (2011) and Niedziałkowska et al. (2016).

Within the highly mixed continental subpopulation, the software BARRIER indicated the presence of lower level migration barriers which separate the demes in north-eastern Poland and the westernmost part of Russia (the Kaliningrad oblast) and deme 14 in the Kirov Oblast, Russia. Genetic distinctiveness of the moose population from north-eastern Poland (particularly the Biebrza River Valley), which is the 
result of the different evolutionary demographic history of this moose group compared to individuals from other surrounding study sites and the location of this deme on the western edge of moose range in Europe, was reported earlier by Świsłocka et al. $(2008,2013,2015)$ and Niedziałkowska et al. (2014, 2016). Although there are no significant topographic barriers for moose in this region, and there is a high level of admixture in this deme (Świsłocka et al. 2008, 2013, 2015; Niedziałkowska et al. 2016, this study), the emigration rate is much higher than the immigration rate to this local population (Świsłocka et al. 2015). This could be explained by higher densities of moose in the Biebrza River Valley than in the surrounding areas (Wawrzyniak et al. 2010). Low immigration to areas of high population density was also detected in the red deer population in north-eastern Poland (Niedziałkowska et al. 2012).

A low level migration barrier separates deme 14; however, the reason for this separation was not clear. This deme is surrounded by large rivers: Vychegda, Severnaya Dvina, Vyatka and Cheptsa, Kama and Volga, which can have a width of a few kilometres. Moose are good swimmers and can swim a distance of at least several kilometres (Dzięciołowski and Pielowski 1975; Hedal 2007). Nonetheless, such large areas of water can constitute some barrier to migration.

Very high gene flow from deme 15 , located in the Arkhangelsk region, to all other demes suggests this is an expansive segment of the European moose population. Northern regions of European Russia have optimal habitats for moose, no topographic barriers to migration, very low human population density and sparse infrastructure. Interestingly, Kangas et al. (2015), who studied moose genetics in Finland and Russian Karelia using mtDNA and microsatellites, reported that moose in Russian Karelia (located west of our deme 15) showed features of an expanding, high-diversity population. Therefore, our results and those of Kangas et al. (2015) show that moose inhabiting the northern part of European Russia may be an expansive, donor population with high migratory potential.

\section{Conclusions}

Our study shows that in the European moose population, significant gene flow occurs at the distance of several hundred kilometres. However, there are significant differences in the migration rates and distances between the two main subpopulations of moose in Europe; this has important implications for the contemporary genetic structure of this species on the continent. Gene flow is more intense and occurs at larger distances within the continental (and especially in its northeastern part) than within the Scandinavian subpopulation. The two moose subpopulations are separated by the Baltic Sea and other topographic barriers in northern Fennoscandia. Lower level migration barriers separate two local demes from the otherwise panmixed continental moose range.

Acknowledgments We thank the personnel of the State Forests, hunters and personnel of the national parks, V. Borodulin, A. N. Bunevich, G. Done, Z. Giżejewski, M. Gustafsson, R. Juškaitis P. Karlsson, U. Karlsson, A. Klemetsen, S. Laaksonen, P. Niemi, L. Persson, R. Veeroja, A. Sagaydak, H. Sand, V. E. Sidorovich, E.J. Solberg, V. A. Solovyev, L. Svensson, J. Tiainen, E. Tulandin, E. Waldemarsson and colleagues from MRI PAS for their help in collecting moose samples. We thank W. Jeedrzejewski for the inspiration during the early stages of the study, H. Zalewska for the laboratory work, M. Górny for the spatial analyses and preparation of maps and Tomasz Diserens for revising the English. We are also grateful to two anonymous referees for the valuable comments. The project was financed by the Polish Ministry of Sciences and Higher Education (grant no. N304 125234), the budget of the Mammal Research Institute PAS in Białowieża and by BIOGEASTBiodiversity of East-European and Siberian large mammals on the level of genetic variation of populations, 7 th Framework Programme (contract nos. 247652 and no. 2096/7. PR UE/2011/2).

\section{Compliance with ethical standards}

Ethical approval All applicable international, national and/or institutional guidelines for the care and use of animals were followed. This article does not contain any studies with human participants performed by any of the authors.

Open Access This article is distributed under the terms of the Creative Commons Attribution 4.0 International License (http:// creativecommons.org/licenses/by/4.0/), which permits unrestricted use, distribution, and reproduction in any medium, provided you give appropriate credit to the original author(s) and the source, provide a link to the Creative Commons license, and indicate if changes were made.

\section{References}

Brincken J (1826) Memoire descriptif sur la foret imperiale de Białowieża en Lithuanie. N. Glücksberg, Varsovie

Bunnefeld N, Borger L, van Moorter B, Rolandsen CM, Dettki H, Solberg EJ, Ericsson G (2011) A model-driven approach to quantify migration patterns: individual, regional and yearly differences. J Anim Ecol 80:466-476

Castric V, Bernatchez L (2004) Individual assignment test reveals differential restriction to dispersal between salmonids despite no increase of genetic differences with distance. Mol Ecol 13:1299-1312

Cornuet JM, Piry S, Luikart G, Estoup A, Solignac M (1999) New methods employing multilocus genotypes to select or exclude populations as origins of individuals. Genetics 153:1989-2000

Dzięciołowski R and Pielowski Z (1975) Łoś. Państwowe Wydawnictwo Rolnicze i Leśne, Warszawa. [In Polish]

Excoffier L, Lischer HEL (2010) Arlequin suite ver 3.5: a new series of programs to perform population genetics analyses under Linux and Windows. Mol Ecol Resour 10:564-567

Falush D, Stephens M, Pritchard JK (2003) Inference of population structure using multilocus genotype data: linked loci and correlated allele frequencies. Genetics 164:1567-1587

Filonov KP (1983) Los. Moscow. Lesnaya Promyshlennost. [In Russian]

Finnegan LA, Wilson PJ, Price GN, Lowe SJ, Patterson BR, Fortin MJ, Murray DL (2012) The complimentary role of genetic and 
ecological data in understanding population structure: a case study using moose (Alces alces). Eur J Wildl Res 58:415-423

Haanes H, Roed KH, Solberg EJ, Herfindal I, Saether BE (2011) Genetic discontinuities in a continuously distributed and highly mobile ungulate, the Norwegian moose. Conserv Genet 12:1131-1143

Harris G, Thirgood S, Hopcraft JGC, Cromsigt JPGM, Berger J (2009) Global decline in aggregated migrations of large terrestrial mammals. Endanger Species Res 7:55-76

Hedal S (2007) Elgens (Alces alces) forekomst pa Sjaelland i nyere tid. [The occasional immigration of moose in Zealand, Denmark in recent times]. Flora og Fauna 113(1):1-5 [In Norwegian with the English abstract]

Hoffman JD, Genoways HH, Choate JR (2006) Long-distance dispersal and population trends of moose in the central United States. Alces 42:115-131

Jędrzejewska B, Jędrzejewski W (1998) Predation in vertebrate communities. The Białowieża Primeval Forest as a case study. Springer, Berlin

Kangas V-M, Kvist L, Kholodova M, Nygrén T, Danilov P, Panchenko D, Fraimout A, Asp J (2015) Evidence of postglacial secondary contact and subsequent anthropogenic influence on the genetic composition of Fennoscandian moose (Alces alces). J Biogeogr 43:2197-2208

Lorenzen ED, Arctander P, Siegismund HR (2008) High variation and very low differentiation in wide ranging plains zebra (Equus quagga) insights from mtDNA and microsatellites. Mol Ecol 17:2812-2824

Mager KH, Colson KE, Groves P, Hundertmark KJ (2014) Population structure over a broad spatial scale driven by nonanthropogenic factors in a wide-ranging migratory mammal, Alaskan caribou. Mol Ecol 23:6045-6057

Manni F, Guérard E, Heyer E (2004) Geographic patterns of (genetic, morphologic, linguistic) variation: how barriers can be detected by "Monmonier's algorithm". Hum Biol 76:173-190

Monmonier M (1973) Maximum-difference barriers: an alternative numerical regionalization method. Geogr Anal 3:245-61

Niedziałkowska M, Fontaine MC, Jędrzejewska B (2012) Factors shaping gene flow in red deer (Cervus elaphus) in seminatural landscapes of central Europe. Can J Zool 90:150-162

Niedziałkowska M, Hundertmark KJ, Jẹdrzejewska B, Niedziałkowski K, Sidorovich VE, Górny M, Veeroja R, Solberg EJ, Laaksonen S, Sand H, Solovyev VA, Shkvyria M, Tiainen J, Okhlopkov IM, Juškaitis R, Done G, Borodulin VA, Tulandin EA, Jędrzejewski W (2014) Spatial structure in European moose (Alces alces): genetic data reveal a complex population history. J Biogeogr 41:2173-2184

Niedziałkowska M, Hundertmark KJ, Jędrzejewska B, Sidorovich VE, Zalewska H, Veeroja R, Solberg EJ, Laaksonen S, Sand H, Solovyev VA, Sagaydak A, Tiainen J, Juškaitis R, Done G, Borodulin VA,
Tulandin EA, Niedziałkowski K (2016) The contemporary genetic pattern of European moose is shaped by postglacial recolonization, bottlenecks, and the geographical barrier of the Baltic Sea. Biol J Linn Soc 117:879-894

Paetkau D, Slade R, Burden M, Estoup A (2004) Genetic assignment methods for the direct, real-time estimation of migration rate: a simulation-based exploration of accuracy and power. Mol Ecol 13: $55-65$

Peakall ROD, Smouse PE (2006) GenAlEx 6: genetic analysis in Excel. Population genetic software for teaching and research. Mol Ecol Notes 6:288-295

Peakall R, Smouse PE (2012) GenAlEx 6.5: genetic analysis in Excel. Population genetic software for teaching and research - an update. Bioinformatics 28:2537-2539

Piry S, Alapetite A, Cornuet JM, Paetkau D, Baudouin L, Estoup A (2004) GENECLASS2: A software for genetic assignment and first-generation migrant detection. J Hered 95:536-539

Pritchard JK, Stephens M, Donnelly P (2000) Inference of population structure using multilocus genotype data. Genetics 155:945-959

Rannala B, Mountain JL (1997) Detecting immigration by using multilocus genotypes. Proc Natl Acad Sci U S A 94:9197-9201

Riley SPD, Pollinger JP, Sauvajot RM, York EC, Bromley CASS, Fuller TK, Wayne RK (2006) A southern California freeway is a physical and social barrier to gene flow in carnivores. Mol Ecol 15:1733-1741

Rozhkov YI, Pronyaev AV, Davydov AV, Kholodova MV, Sipko TP (2009) Los: populacionnaya biologiya i mikroevolyuciya. KMK Scientific Press, Moscow, Russia [In Russian with English summary]

Singh NJ, Borger L, Dettki H, Bunnefeld N, Ericsson G (2012) From migration to nomadism: movement variability in a northern ungulate across its latitudinal range. Ecol Appl 22:2007-2020

Świsłocka M, Ratkiewicz M, Borkowska A, Komenda E, Raczyński J (2008) Mitochondrial DNA diversity in the moose, Alces alces, from northeastern Poland: evidence for admixture in a bottlenecked relic population in the Biebrza valley. Ann Zool Fenn 45:360-365

Świsłocka M, Czajkowska M, Duda N, Danylow J, Owadowska-Cornil E, Ratkiewicz M (2013) Complex patterns of population genetic structure of moose, Alces alces, after recent spatial expansion in Poland revealed by sex-linked markers. Acta Theriol 58:367-37

Świsłocka M, Czajkowska M, Duda N, Ratkiewicz M (2015) Admixture promotes genetic variation in bottlenecked moose populations in eastern Poland. Mamm Res 60:169-179

Wawrzyniak P, Jedrzejewski W, Jedrzejewska B, Borowik T (2010) Ungulates and their management in Poland. In: Apollonio M, Andersen R, Putman R (eds) European ungulates and their management in the 21st century. Cambridge University Press, Cambridge, pp 223-242 